ايقان: المجلد:ا ـ، العدد:r.: يونيو 19. بـ

دراسة مقارنة في تعيين الزمان والمكان والأعلام عند شراح البخاري

(الكرماني وابن حجر نموذجاً)

\title{
Study on determining the Period, places and names in Sahih Bukhari (application on Asqalani and Kirmani)
}

\author{
Dr. Mati ur Rehman \\ Assistant Professor, Department Islamic studies \\ Islamabad Model College (Boys), Islamabad, Pakistan. \\ Dr. Fat'h ur Rehman Qurashi, \\ Chairman Department of Hadith \& sciences, \\ Islamic International University, Islamabad, Pakistan.
}

\begin{abstract}
$\underline{\text { ABSRACT }}$
Sahih al-Bukhari by Imam Abu Abdullah Mohammad al-Bukhari comes second to the Holy Quran as a fundamental source of Islam. It is a most authentic collection of sayings and deeds of Prophet Mohammad $(P B U H)$, which covers almost all aspects of life in providing proper guidance from the Messenger of Allah. The Muslim scholars of past and present time gave great importance to this book by making their efforts to extract the hidden treasures from this book and to present the different approaches and benefits of this book. "Al Kawakib Ad Durari" by Imam Alkirmani is an old explanation of Sahih Bukhari. During studying "Fath al Bari" I found that Alhafiz Ibne Hajar has consulted "Al Kawakib Ad Durari" and quoted Imam Alkirmani's commentary and added it. Alhafiz Ibn e Hajar differs at many times with the opinions of Imam Alkirmani about specific time, place, different tribes and personalities mentioned in the text of traditions. I wanted to study such analysis to check the right opinion after comparing statements of both Imams and by consulting with the statements of other scholars of this field. This article approves that judgments of Ibn e Hajar about specific time, place, different tribes and personalities are more authentic than opinions of imam Alkirmani.
\end{abstract}

Key words: Al-hafiz Ibn e Hajar, Imam Alkirmani, Fath al Bari, Al Kawakib Addarari 
دراسة في تعيين الزمان والأماكن و القبائل والأسماء في صحيح البخاري

الحمد لله رب العالمين، و الصلوُة والسلام على اشرف الانبياء والمرسلين، اما بعد؛

الجامع الصحيح للبخاري هو أصحّ الكتب بعد القرآن الكريم، واهتم العلماء بدراسته في كل

العصوروبذلوا جهدهم في شرحه وبيان فوائده وتفسير تراجمه وبيان مناسبتها للأحاديث الواردة تحتها ـ ومن الشروح المتقدمة لصحيح البخاري ’الكواكب الدراري، للإمام شمس الدين أبو عبد الله محمد بن يوسف الكرماني، قد استفاد منه معظم الشرّاح جاؤوا بعده. أثناء قراءتي لفتح الباري وجدت أن الحافظ ابن حجر تعقب على الكرماني في عدة مو اضع في تعيين الزمن و المكان والقبائل والأسماء في متون الأحاديث فرغبتي أن أقوم بدراسة هذه التعقبات لتحقق الرأي الصائب فيها بعد مقارنة العبارات لكلا الإمامين و ذلك برجوع إلى روايات أخرى و بمعرفة أقوال العلماء في شروح الأحاديث.

المبحث الأول:تعقبات ابن حجر على الكرماني في تعيين الزمن والمكان في الأحاديث:

التعقب في تعيين 'غَزْوْوَة السَّابِعَِِّة:

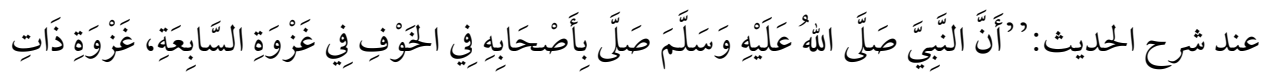
الرِّقَاع، ، 1قال العلامة الكرماني:

”والغزوة السابقة (أي من غزوات النبي صلى الله عليه وسلم ) وفي بعضها غزوة السابعة أي غزوة

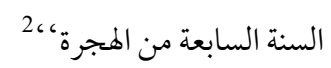

جزم العلامة الكرماني أن غزوة ذات الرقاع في السنة السابعة من الهجرة. وبعد ذكر قول الكرماني تعقب عليه الحافظ بقوله: "قلت وفي هذا التقدير نظر، 3ثم ذكر عدة أقوال في تاريخ الوقعة وأخيرا جزم الحافظ على رأي:

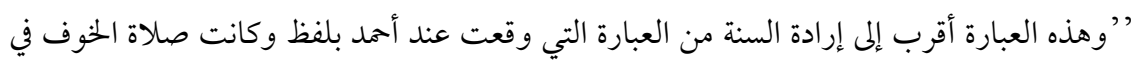

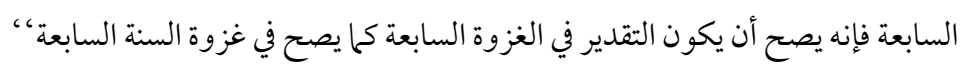

فبهذا القول زال تعقبه على العلامة الكرماني.أقول ومعظم الشراح قالوا عند شرح الحديث أن الإمام البخاري ذهب إلى أن ذلك كان بعد خيبر مثلاً قال العيني:

1 بخاري ، محمد بن اسماعيل ،الجامع الصحيح (بيروت:دار طوق النجاة، 1422هـ)، ح: 4125

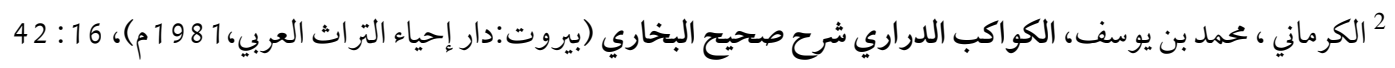

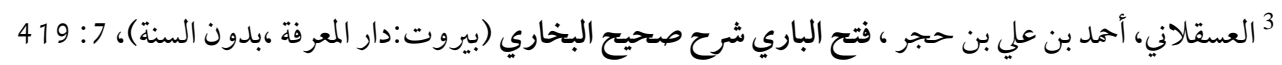




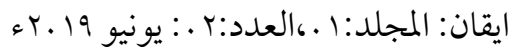

"أما غزوة ذات الرقاع فقد ذكرها ابن إسحاق أنها كانت بعد غزوة بني النضير بشهرين، وغزوة بني ئمئ

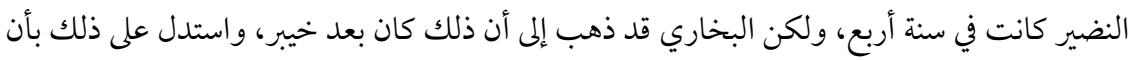

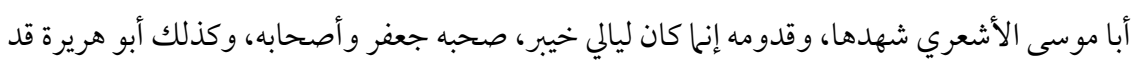

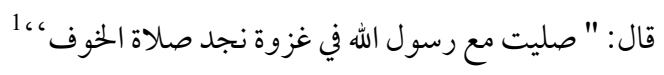

أقول تعقب الحافظ على الكرماني أولا ولكنه في الأخير ذهب إلى نفس الإحتمال الذي جزم به الكرماني،

$$
\text { فتعقبه في غير محله و الله أعلم. }
$$

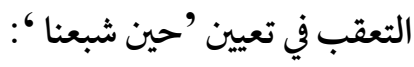

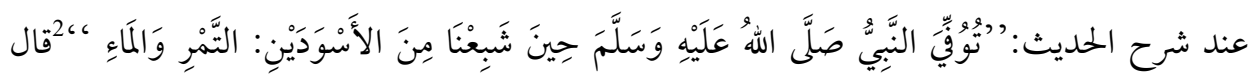

$$
\text { العلامة الكرماني: (n) }
$$

” (حين شبعنا) ظرف معناه ما شبعنا قبل زمان وفاته يعني كنا مقللين من الدنيا زاهدين فيها، ، 3

$$
\text { قال الحافظ ابن حجر: - ماف }
$$

"حديث عائشة توفي النبي صلى الله عليه و سلم حين شبعنا من الأسودين التمر والماء وفيه إشارة إلى أن شبعهم لم يقع قبل زمان وفاته قاله الكرماني قلت لكن ظاهره غير مراد وقد تقدم في غزوة خيبر من

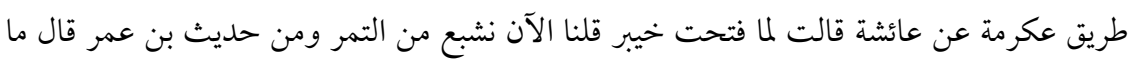
شبعنا حتى فتحنا خيبر فالمراد أنه صلى الله عليه و سلم شبع حين شبعوا واستمر شبعهم وابتداؤه من فتح خيبر وذلك قبل موته صلى الله عليه و سلم بثلاث سنين ومراد عائشة بما اشارت إليه من الشبع هو

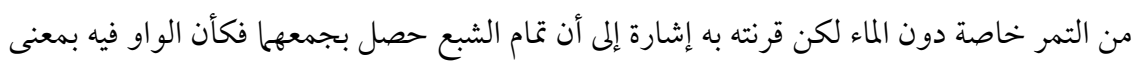
مع لا أن الماء وحده يوجد الشبع منه ولماعبرت عن التمر بوصف واحد وهو السو ادعبرت عن الشبع

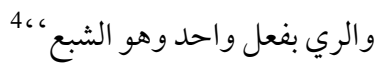

المراد من قولها ”توفي النبي صلى الله عليه و سلم حين شبعنا،" عكس ما قاله العلامة الكرماني لأن بهذا

$$
\begin{aligned}
& \text { 1 العينى، محمود بن أحمد، شرح سنن أبي داود (الرياض:مكتبة الرشد } 1999 \text { م)، } 5: 111 \\
& \text { 2البخاري ، الجامع الصحيح ، ح: } 5383
\end{aligned}
$$

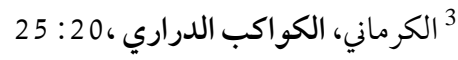

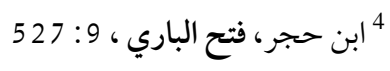


دراسة في تعيين الزمان والأماكن والقبائل والأسماء في صحيح البخاري

$$
\text { المر اد يتعارض الحديث بها رواه الإمام البخاري في كتاب المغازي قال: }
$$

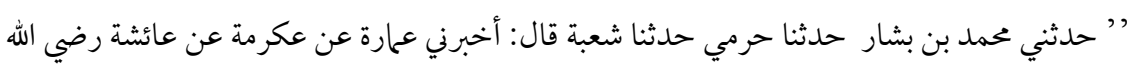

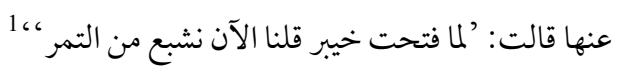

فالمراد الذي ذكره الحافظ هو أقرب إلى الصواب ويه قال أكثر الشراح مثلاً قال العيني:

"قوله حين شبعنا ظرف كالحال معناه ما شبعنا قبل زمان وفاته يعني كنا متقللين من الدينا زاهدين فيها

هكذا فسره الكرماني وليس معناه هكذا و إنما معناه توفي النبي وقت كوننا شباعى من الأسودين والدليل

على صحة ما قلنا ما مضى في غزوة خيبر من طريق عكرمة عن عائشة قالت لما فتحت خيبر قلنا الآن

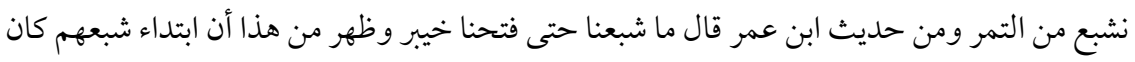

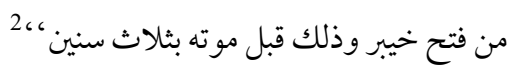

أقول: بعد دراسة كلا القولين وصلت إلى أن المعنى الذي ذكره الحافظ من قول عائشة رضي الله عنها هو

$$
\begin{aligned}
& \text { أقرب إلى الصواب، فتعقبه على العلامة الكرماني في محله والله أعلم. } \\
& \text { التعقب في تعيين التاريخ: }
\end{aligned}
$$

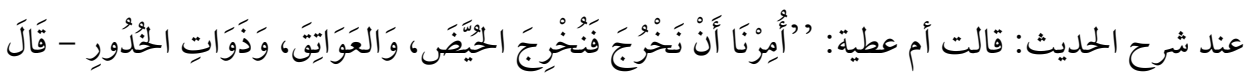

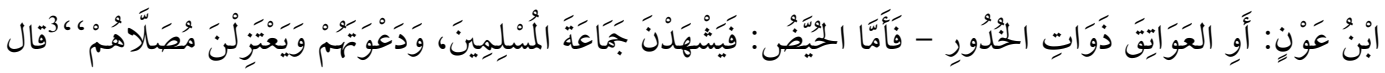
العلامة الكرماني:

"وقال الطحاوي: يحتمل أن يكون هذا الأمر في أول الإسلام والمسلمون قليل فأريد التكثير

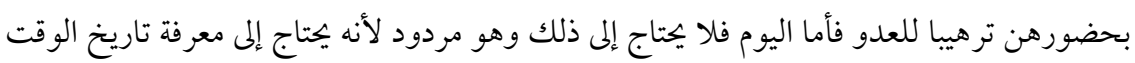

$$
\text { وقالنخ لا يثبت إلا بيقين، ،4 }
$$

”قال الكرماني تاريخ الوقت لا يعرف قلت بل هو معروف بدلالة حديث بن عباس أنه شهده وهو

$$
\begin{aligned}
& \text { 1 البخاري ، الجامع الصحيح ، ح: } 4242 \\
& \text { 2 العينى، عمدة القاري، 30: } 327 \\
& 3 \\
& \text { 4 الكرمانى، الكواكب الدراري، 6: } 83
\end{aligned}
$$


رد العلامة الكرماني قول الطحاوي عن نسخ هذا الحديث حيث قال الكرماني "وهو مردود لأنه يجتاج إلى معرفة تاريخ الوقت والنسخ لا يثبت إلا بيقين، أراد العلامة الكرماني أن دعوى النسخ لا يقوم على أي دليل بل إعتماد هذا القائل على الظن والتخمين. ويظهر من كلام الكرماني أنه لا يعرف معرفة تاريخ الوقت، ولكن هذا يعرف

$$
\text { من حديث ابن عباس رضي الله عنهما أخرجه الإمام البخاري قال: }
$$

”قال ابن جريج: وأخبرني الحسن بن مسلم، عن طاوس، عن ابن عباس رضي الله عنها، قال: شهدت

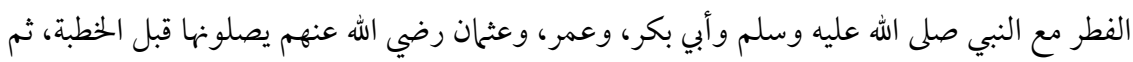

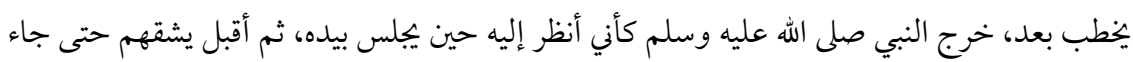

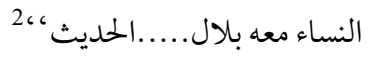

وتعقب الحافظ على الكرماني وأشار إلى هذا الحديث وعرفنا تاريخ الوقت وهو بعد فتح مكة، أقول: أشار الحافظ إلى حديث ابن عباس رضي الله عنها وبه نعرف تاريخ الوقت وهذا لم يذكره العلامة الكرماني فتعقب الحافظ في محله والله أعلم.

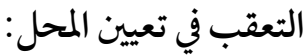

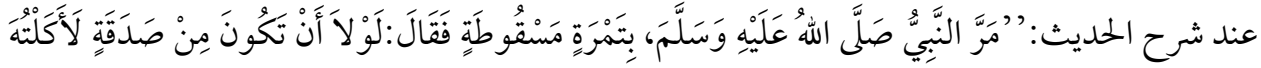

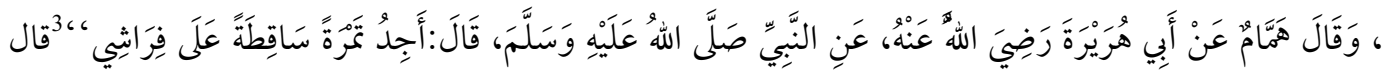
العلامة الكرماني: "فإن قلت ما تعلقه بهذا الباب؟ تمام الحديث غير مذكور وهو ’لو لا أن تكون صدقة لأكلتها، ارتاب رسول الله صلى الله عليه وسلم في تلك التمرة أهي من الصدقة التي تحرم عليه أم هي من ماله فترك أكلها

$$
\begin{aligned}
& \text { تنز ها من شبهة، ، } 4 \\
& \text { وقال الحافظ ابن حجر: } \\
& \text { 1 } 1 \text { ابن حجر، فتح الباري، 2: } 40 \\
& 2 \\
& \text { 3 ايضاً، ح: } 2055
\end{aligned}
$$

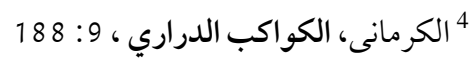


دراسة في تعيين الزمان والأماكن والقبائل والأسماء في صحيح البخاري

”قوله وقال همام الخ وصله في اللقطة بتحامه ولفظه أني لأنقلب إلى أهلي فأجد التمرة ساقطة على فراشي فارفعها لاكلها ثم أخشى أن تكون صدقة فالقيها قلت ولم يستحضر الكرماني لفظ رواية همام فقال تمام الحديث غير مذكور وهو لو لا أن تكون صدقة لأكلتها قلت والنكتة في ذكره هنا ما فيه من تعيين المحل

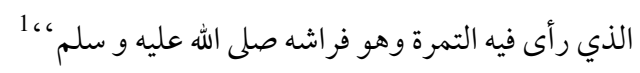
وصل الإمام البخاري تعليق همام في كتاب اللقطة قال: "وقال يميى حدثنا سفيان حلثني منصور وقال زائدة عن منصور عن طلحة حدثنا أنس وحدثنا عحمد بن مقاتل أخبرنا عبد الله أخبرنا معمر عن همام بن منبه عن أبي هريرة رضي الله عنه عن النبي صلى الله

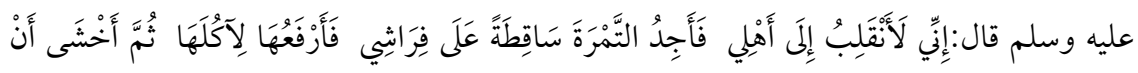

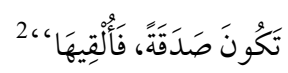

لو كان العلامة الكرماني يقف على تمام الحديث في اللقطة لما تردد في فهم مطابقة تعليق المذكور وبالرواية التي أخرجه الإمام البخاري في اللقطة عرفنا المكان الذي رأى فيه التمرة وهو فراشه صلى الله عليه و سلم ولهذا كان النبي صلى الله عليه و سلم واجه الشبهة وتنزه عنه وبهذا التوجيه يطابق الحديث بالترجمة صراحة. وإلى هذا أشار الحافظ تعقبا على العلامة الكرماني.أقول: بعد دراسة كلا القولين توصلت إلى أن ما ذكره الحافظ ابن حجر هو أقرب

$$
\text { إلصواب وبه زال تردد العلامة الكرماني. }
$$

\section{المبحث الثاني:تعقبات ابن حجر على الكرماني في تعيين القبائل والأسماء في الأحاديث:}

وقفت على اثنين وعشر موضعا استدرك الحافظ فيها على الكرماني في تعيين القبائل والأسماء في الأحاديث

وناقشت فيها وبينت الراجح منها بتوفيق الله تعالى.

التعقب في تعيين القبيلة 'بني جزيمة':

عند شرح الحديث: "باب بعث النبي صلى الله عليه وسلم خالد بن الوليد إلى بني جذيمة، ،قال العلامة

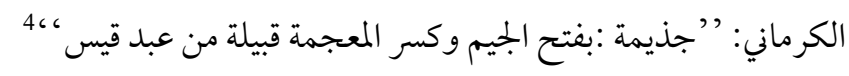

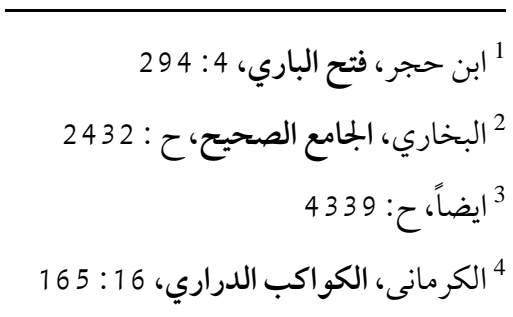




$$
\text { وقال الحافظ ابن حجر: - مجر: }
$$

"قوله باب بعث النبي صلى الله عليه و سلم خالد بن الوليد إلى بني جذيمة :بفتح الجيم وكسر المعجمة

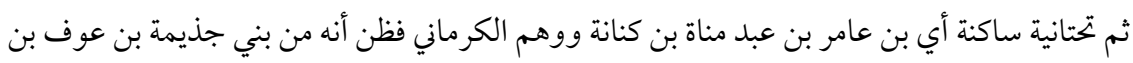

$$
\text { بكر بن عوف قبيلة من عبد قيس، ، } 1 \text { كاب }
$$

ما قاله العلامة الكرماني في تعيين قبيلة بني جذيمة هو لم يصح لأن العلماء نسبوا هذه القبيلة إلى عبد مناة

$$
\text { بن كنانة،مثلاً قال ابن الأثير: }
$$

"ولما فتح رسول الله صلى الله عليه و سلم مكة بعثه إلى بني جذيمة من بني عامر بن لؤي، ،2

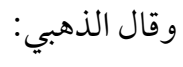

”قال ابن إسحاق: وبعث رسول الله صلى الله عليه وسلم السرايا فيها حول مكة يدعون إلى الله تعالى، ولم يأمرهم بقتال. فكان ممن بعث خالد بن الوليد وأمره أن يسير بأسفل تهامة داعيا ولم يبعثه مقاتلا.

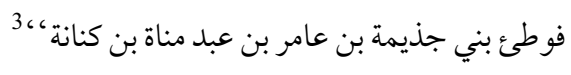

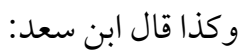

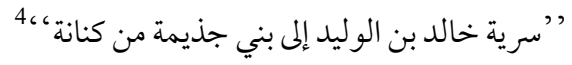

$$
\text { وتعقب على العلامة الكرماني غير الحافظ من العلماء مثلاً قال العيني: }
$$

”بني جذيمة بفتح الجيم وكسر الذال المعجمة بعدها ياء آخر الحروف ساكنة وهي قبيلة من جذيمة عبد

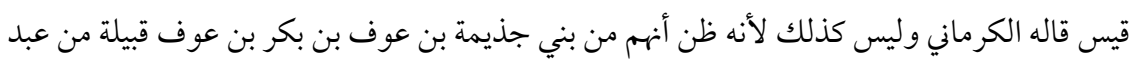

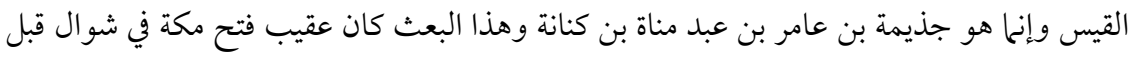

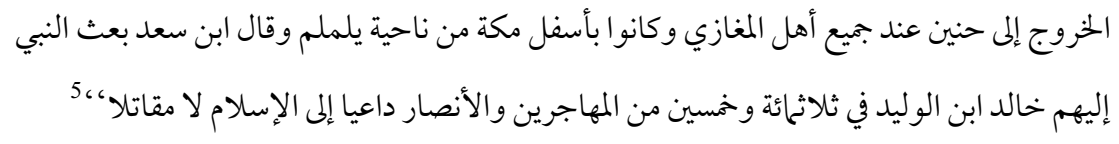

2 ابن الأثير ، علي بن محمد ، أسد الغابة في معرفة الصحابة (بيروت:دار ابن ابن حزم، 12 201م)، 1: 312

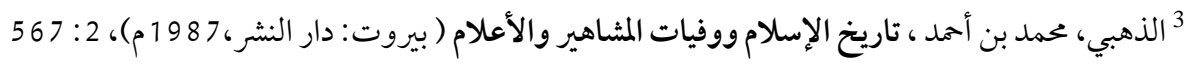

4 الزهري، محمد بن سعد ، الطبقات الكبرى (بيروت: دار صادر، بدون السنة )، $2: 147$

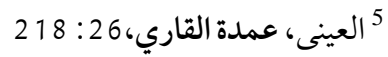


دراسة في تعيين الزمان والأماكن والقبائل والأسماء في صحيح البخاري

أقول: بعد البحث وصلت إلى أن في القصة المذكورة نسبة قبيلة جذيمة إلى عبد قيس غير صحيح بل هي قبيلة بن عامر بن عبد مناة بن كنانة فتعقب الحافظ في محله والله أعلم. التعقب في تعيين القبيلة 'أبي إسرائيل؛':

عند شرح الحديث:" حدثنا موسى بن إسماعيل حدثنا وهيب حدثنا أيوب عن عكرمة عن ابن عباس قال

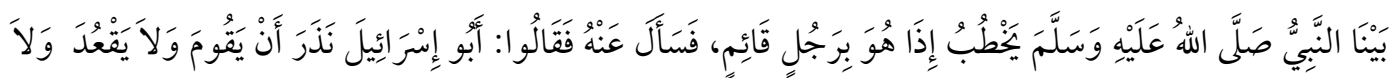

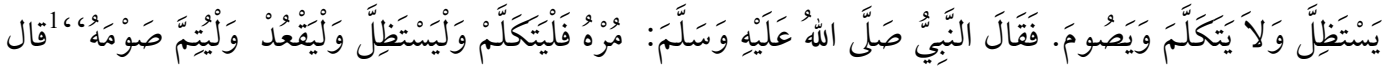
العلامة الكرماني: - n

”قوله (أبو إسرائيل) هو كنية الرجل الناذر للقيام وهو من الأنصار واسمه يسير مصغر ضد العسر،2، وقال الحافظ ابن حجر: "و أبو إسرائيل المذكور لا يشاركه أحد في كنيته من الصحابة واختلف في اسمه فقيل قشير بقاف وشين معجمة مصغر وقيل يسير بتحتانية ثم مهملة مصغر أيضا وقيل قيصر باسم ملك الروم وقيل بالسين المهملة بدل الصاد وقيل بغير راء في آخره وهو قرشي ثم عامري وترجم له بن الأثير في الصحابة تبعا

لغيره فقال أبو إسرائيل الأنصاري واغتر بذلك الكرماني فجزم بأنه من الأنصار والأول أولى ،3، لم يذكر الحافظ وجه إختيار الإحتمال أن أبو إسرائيل هو قرشي وعدّه العلماء من الأنصار فقال ابن الأثير:

$$
\text { وقال وابو إسرائيل الأنصاري يعد في أهل المدينة له صحبة، ،4 }
$$

"أبو اسرائيل رجل من الأنصار من أصحاب النبي صلى الله عليه وسلم نذر ألا يتكلم وأن يقف صائمًا.

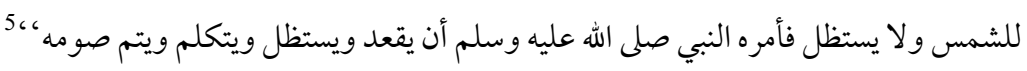
ويظهر أيضا من كلام الحافظ في الإصابة أنه لم يمزم بكونه من قريش حيث قال:

$$
\begin{aligned}
& \text { 1 البخاري ، الجامع الصحيح ،ح: } \\
& \text { 2² الكرمانى، الكواكب الدراري ، } 23 \text { : } 136
\end{aligned}
$$

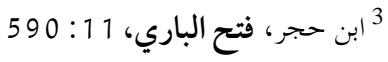

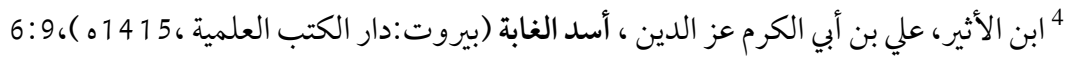

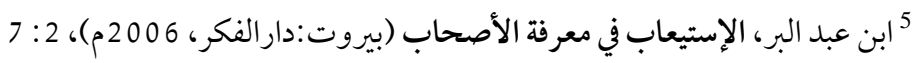




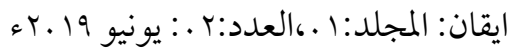

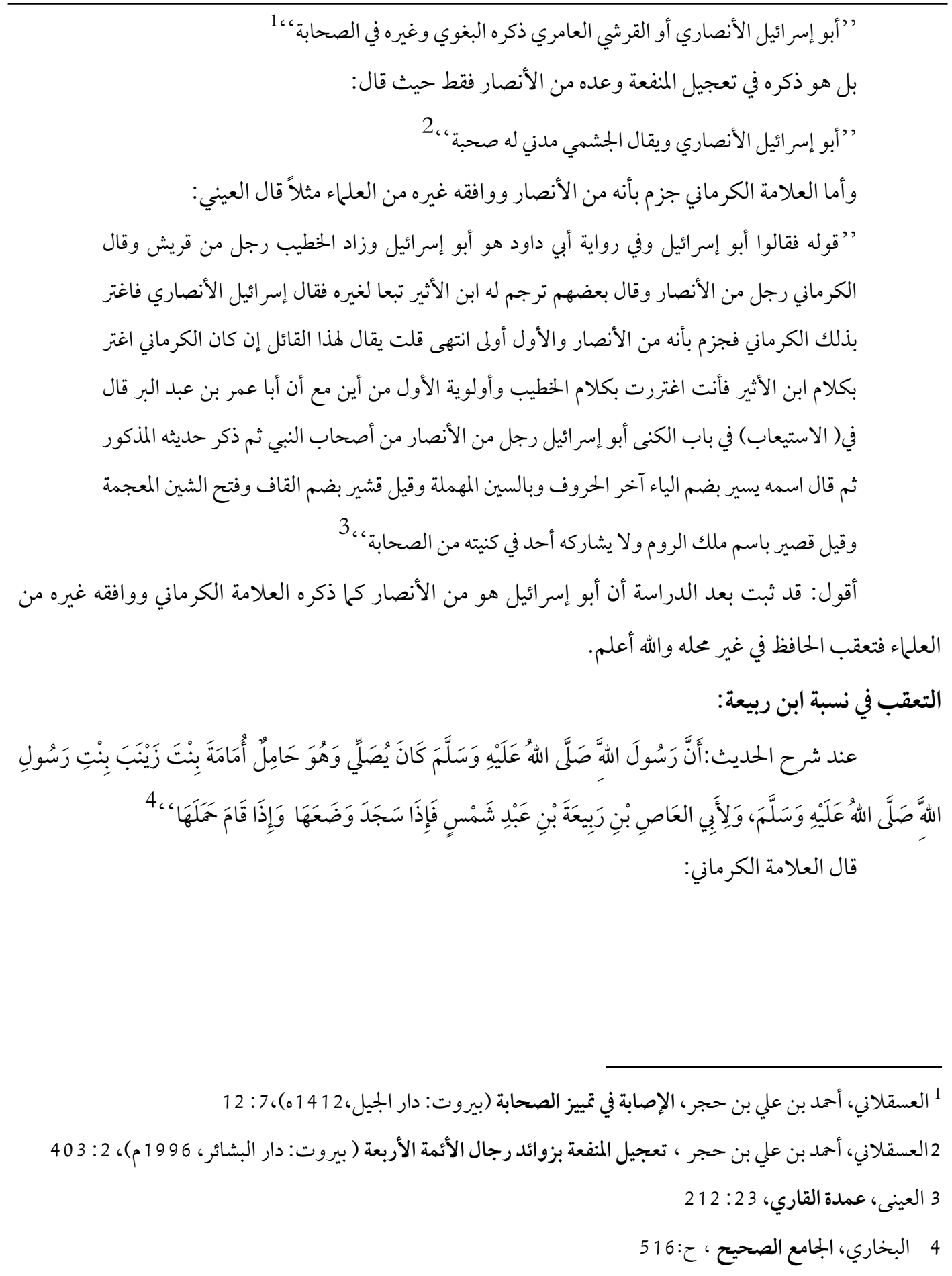


دراسة في تعيين الزمان والأماكن والقبائل و الأسماء في صحيح البخاري

"و اعلم أن البخارى نسبه مخالفا للقوم من جهتين قال ربيعة بحرف التأنيث وعندهم الربيع بدونه وقال

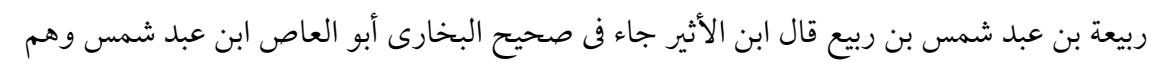

قالو ا ربيع بن عبد العزى بن عبد شمس وذلك خلاف الجماعة ، 1

وقال الحافظ ابن حجر:

"قوله بن ربيعة بن عبد شمس كذا رواه الجمهور عن مالك ورواه يحيى بن بكير ومعن بن عيسى وأبو

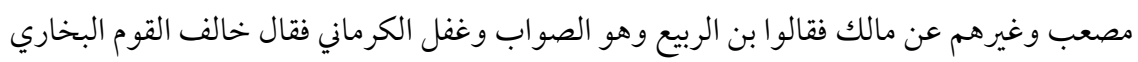

فقال ربيعة وعندهم الربيع والواقع أن من أخرجه من القوم من طريق مالك كالبخاري فالمخالفة فيه إنما

هي من مالك وادعى الأصيلي أنه بن الربيع بن ربيعة فنسبه مالك مرة إلى جده ورده عياض والق والقرطبي

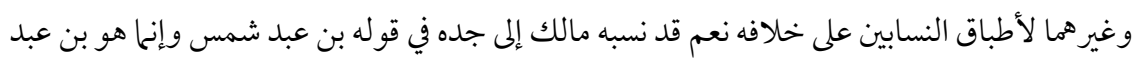

العزى بن عبد شمس أطبق على ذلك النسابون أيضا، ، 2

أخرج الإمام مالك هذا الحديث من طريق عامر بن عبد الله بن الزبير عن عمرو بن سليم الزرقي عن أبي

قتادة الأنصاري أن رسول الله صلى الله عليه وسلم كان يصلي وهو حامل أمامة بنت زينب بنت رسول الله صلى الله عليه وسلم و لأبي العاص بن ربيعة بن عبد شمس فإذا سجد وضعها وإذا قام حملها 3. تعقب العلامة الكرماني على الإمام البخاري إعتمادا على قول ابن الأثير وادعى أن الإمام البخاري قال: 'بن ربيعة' فبهذا هو خالف القوم لأن الجمهور قالوا: 'بن الربيع ولكن هذه المخالفة ليس من قبل البخاري بل المخالفة فيه إنها هي من مالك؛ روى بعض بـ بـ

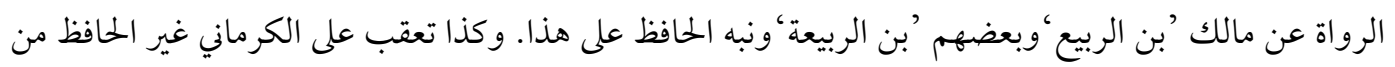

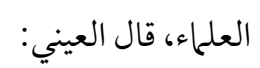

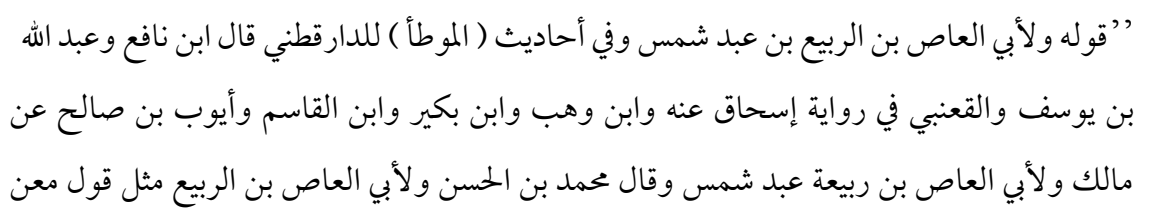

1

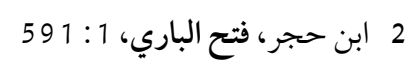

3 الامام ، مالك ابن أنس بن مالك ،الموطأ ،(بيروت :دار إحياء التراث العربي، 1406 هـ) ، ح: 589 


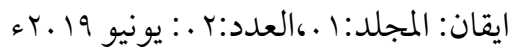

$$
\begin{aligned}
& \text { و أبي مصعب و........ قلت لو اطلع الكرماني على كلام القوم لما قال نسبة البخاري مخالفا للقوم من }
\end{aligned}
$$

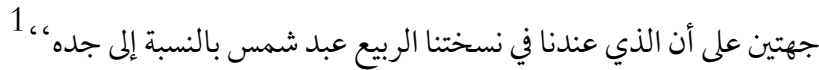

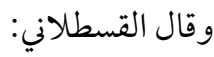

$$
\begin{aligned}
& \text { ’بن ربيعة: بن عبد العزى (بن عبد شمس) كذا وقع في رواية الأكثرين عن مالك، والصواب ما رواه } \\
& \text { أبو مصعب ومعن بن عيسى ويميى بن بكير عن مالك الربيع بلا هاء ونسبه مالك إلى جدّه لشهرته به، بـ } 2
\end{aligned}
$$

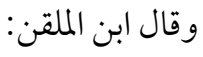

"وقوله: ربيعة، كذا رواه البخاري وأكثر رواة 'الموطأُعن مالك وقيل إنه نسبه إلى الجد، والمعروف أنه

$$
\text { ابن الربيع ونسب أمامة إلى أمها دونه لأجل الشرف، ، } 3
$$

أقول: بعد دراسة أقوال العلماء وصلت إلى أن الإمام البخاري لم يخالف هنا الجمهور في نسبة بن ربيعة كما

نبه العلامة الكرماني بل هذا الإختلاف وقع في رواية عن مالك والصواب ما قاله الحافظ وتعقبه على الكرماني في محله و الله أعلم.

$$
\text { التعقب في نسبة أم عباس : }
$$

عند شرح الحديث: ' "حدثني إبراهيم بن المنذر حدثنا محمد بن فليح عن موسى بن عقبة قال ابن شهاب:

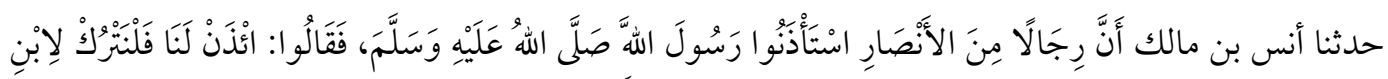

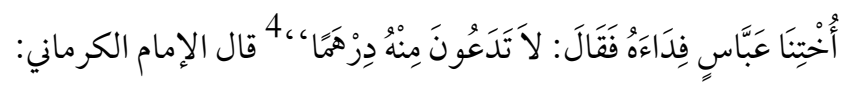

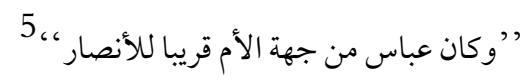

"وقال الحافظ ابن حجر: قوله لابن أختنا عباس أي بن عبد المطلب وأم العباس ليست من الأنصار بل

جدته أم عبد المطلب هي الأنصارية فأطلقوا على جدة العباس أختا لكونها منهم وعلى العباس ابنها

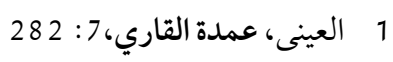

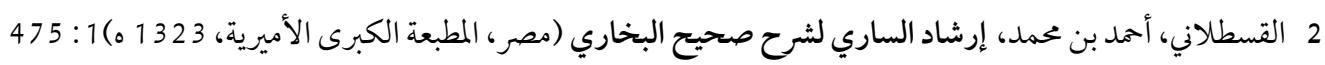
3 ابن الملقن، عمر بن علي ، التوضيح لشرح الجامع الصحيح (دمشق :دار الفلاح للبحث العلمي، بدون السنة) 7 المبحري 4 البخاري، الجامع الصحيح ، ح:4 4017 5 الكرمانى، الكواكب الدراري، 15: 192 
دراسة في تعيين الزمان والأماكن و القبائل والأسماء في صحيح البخاري

لكونها جدته وهي سلمى بنت عمرو بن زيد بن لبيد من بني عدي بن النجار ثم من بني الخزرج وأما أم

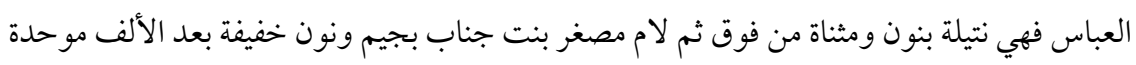

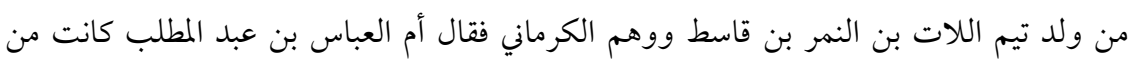

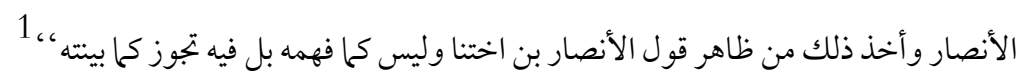
ذكر العلماء في ترجمة عباس بن عبد المطلب رضي الله عنه إسم أمه نتيلة بنت جناب بن كليب بن مالك بن عبد مناف فهي ليست من الأنصار وأما اسم أم عبدالمطلب فهي سلمى بنت عمرو بن زيد بن لبيد بن حرام بن خداش بن عامر بن غنم بن عدي بن النجار ــ وهي من قبيلة الخزرج.فأخطأ العلامة الكرماني حين نسب أم عباس إلى الأنصار ولهذا تعقب عليه الحافظ وغيره من العلماء مثلاً قال العيني: "قوله لابن أختنا عباس وكان عباس من جهة الأم قريبا للأنصار كذا قاله الكرماني وسكت عليه وأم العباس وهو ابن عبد المطلب ليست من الأنصار بل جدته أم عبد المطلب هي الأنصارية فأطلق على فئل جدة العباس أختنا لكونها منهم وعلى العباس ابنها لكونها جدته وأم العباس وضرار نثيلة ...- وكان هاشم والد عبد المطلب لما مر بالمدينة نزل على عمرو بن زيد المذكور وكان سيد قومه فأعجبته ابته سلمى فخطبها إلى أبيها وزوجها منه، ، 3 أقول: قد ثبت بعد الدراسة أن أم عباس بن عبدالمطلب ليست من الأنصار كما زعم العلامة الكرماني بل

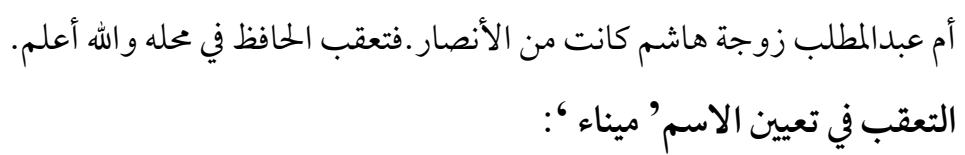

عند شرح الحديث: ' حدثنا ابن أبي مريم حدثنا أبو غسان، قال: حدثني أبو حازم عن سهل رضي الله

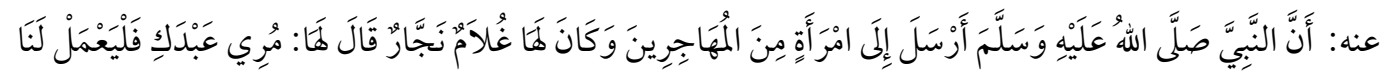

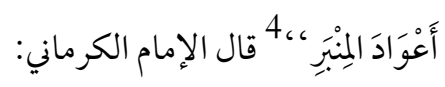

1

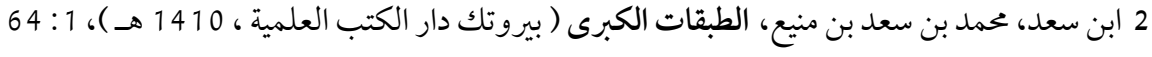

3 العينى، عمدة القاري، 252 4 البخاري، الجامع الصحيح ‘ح: 2569 


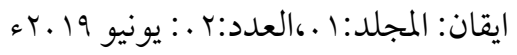

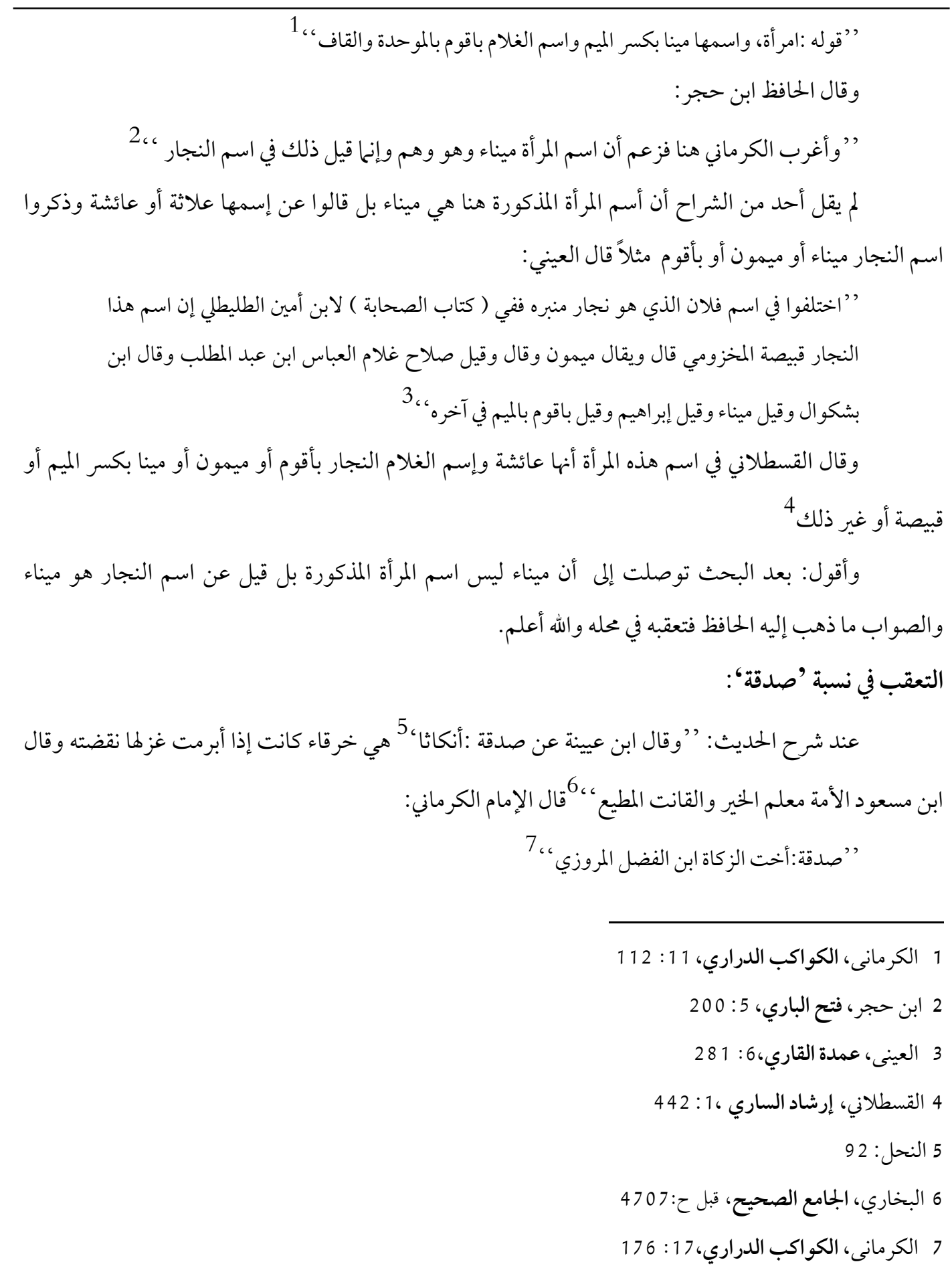


دراسة في تعيين الزمان والأماكن والقبائل والأسماء في صحيح البخاري

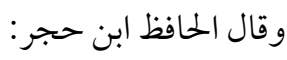

"وقد أقدم الكرماني فقال صدقة هذا هو بن الفضل المروزي شيخ البخاري وهو يروي عن سفيان بن

عيينة وهنا روى عنه سفيان ولا سلف له فيها ادعاه من ذلك ويكفي في الرد عليه ما أخرجناه من تفسير

بن جرير وابن أبي حاتممن رواية صدقة هذا عن السدي فإن صدقه بن الفضل المروزي ما أدرك السدي

ولا أصحاب السدي وكنت أظن أن صدقة هذا هو بن أبي عمران قاضي الأهواز لأن لابن عيينة عنه

رواية إلى أن رأيت في تاريخ البخاري صدقة أبو الهذيل روى عن السدي، ولـ 1

صدقة هنا ليس ابن الفضل المروزي ولا هو صدقة بن أبى عمران بل هو صدقة بن عبد الله بن كثير المكى

القارئ أبو الهذيل بن سفيان يروي عنه وهو يروي عن السدي أما صدقة بن الفضل المروزي فلم يدرك السدي.

ويظهر هذا من أقو ال العلم)ء.قال الطبري:

”حدثنا المثنى قال: ثنا إسحاق قال: ثنا عبد الله بن الزبير عن ابن عيينة عن صدقة عن السدي:وَلَا

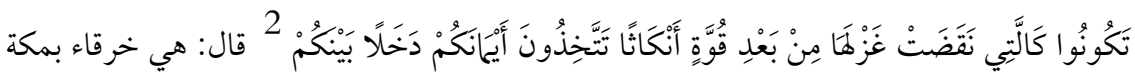

$$
\text { و كانت إذا أبرمت غزلها نقضته، ، } 3
$$

"هو صدقة بن عبد الله بن كثير المكي القارئ أبو الهذيل صاحب حروف بجاهد روى عن السدي روى

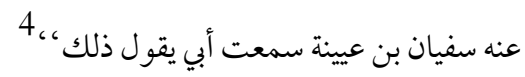

فقول الكرماني أن صدقة ابن الفضل المروزي غير صحيح وتعقبه غير الحافظ من العلماء قال العيني:

قال الكرماني صدقة هذا هو ابن الفضل المروزي ورد عليه بأن صدقة بن الفضل المروزي شيخ البخاري

يروى عن سفيان بن عيينة وههنا يروي سفيان عن صدقة والدليل على عدم صحة قوله إن صدقة هذا

روى عن السدي وصدقة بن الفضل المروزي ما أدرك السدي ولا أصحاب السدي وروى البن أبي

حاتمعن أبيه عن ابن أبي عمر العدني والطبري من طريق الحميدي كلاهما عن ابن عيينة عن صدقة عن

1 ابن حجر، فتح الباري، 8 : 387

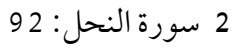

3 الطبري، محمد بن جرير جامع البيان في تأويل القرآن (بيروت: مؤسسة الرسالة، 1420 هـ)، 17 : 174 4 الرازي، عبد الرحمن بن أبي حاتم، الجرح والتعديل (مصر:دار الكتب العلمية، 137 130)، 4: 433 


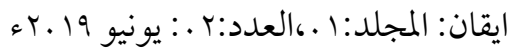

السدي قال كانت بمكة امرأة تسمى خرقاء فذكر مثل ما ذكره البخاري والظاهر أن صدقة هذا هو أبو

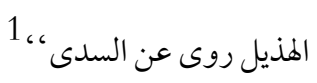

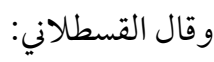

”عن صدقة:أبي الهذيل لا صدقة ابن الفضل المروزي أي عن السدي كا عند ابن أبي حاتم،،2 2 أقول: بعد البحث توصلت إلى أن صدقة هو بن عبد الله بن كثير المكى أبو الهذيل وهذا الإحتمال جزم به إبه الحافظ وهو أقرب إلى الصواب أما كون صدقة ابن الفضل المروزي لم يثبت.فتعقب الحافظ في محله والله أعلم. التعقب في نسبة 'ابن الدغنة 6؛ عند شرح الحديث:" "عائشة رضي الله عنها قالت لم أعقل أبوي قط إلا وهما يدينان الدين ولم يمر علينا يوم إلا ياتينا فيه رسول الله صلى الله عليه وسلم طرفي النهار بكرة وعشية فلما ابتلي المسلمون خرج أبو بكر مهاجرا قبل الحبشة حتى إذا بلغ برك الغهاد لقيه ابن الدغنة وهو سيد القارة فقال أين تريد يا أبا بكر فقال أبو بكر أخرجني قومي فأنا أريد أن أسيح في الأرض فأعبد ربي قال ابن الدغنة إن مثلك لا يخرج ولا يخرج............ الحديث الطويل، ، 3

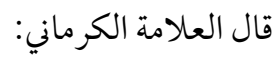

"قوله :ابن الدغنة،الغساني: هو بفتح المهملة وكسر المعجمة وخفة النون على مثال الكلمة ويقال بضم الدال والغين وتشديد النون وبالوجهين رويناه في الجامع ويقال بفتح الدال وسكون الغين. وقال ابن إسحاق اسمه ربيعة بن رفيع وأما الدغنة فهو اسم أمه ومعناه لغة: الغيم الممطر، ، 4

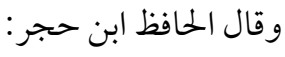
”قو له بن الدغنة بضم المهملة والمعجمة وتشديد النون عند أهل اللغة وعند الرواة بفتح أوله وكسر ثانيه وتخفيف النون قال الأصيلي وقرأه لنا المروزي بفتح الغين وقيل إن ذلك كان لاسترخاء في لسانه و الصو اب الكسر وثبت بالتخفيف والتشديد من طريق وهي أمه وقيل أم أبيه وقيل دابته ومعنى الدغنة 
دراسة في تعيين الزمان والأماكن و القبائل والأسماء في صحيح البخاري

المسترخية وأصلها الغمامة الكثيرة المطر واختلف في اسمه فعند البلاذري من طريق الواقدي -...الدغنة

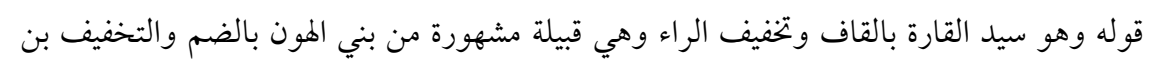
خزيمة بن مدركة بن إلياس بن مضر وكانوا حلفاء بني زهرة من قريش وكانوا يضرب بهم المثل في قوة

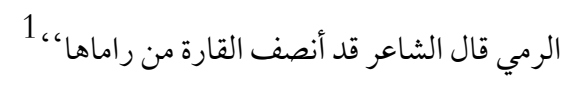
ذكر العلامة الكرماني قول ابن إسحق في ابن الدغنة أن اسمه ربيعة بن رفيع وأقول ولكن ابن الدغنة في

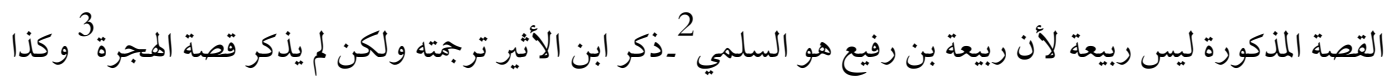
ذكره ابن عبدالبر بدون ذكر قصة الهجرة وذكره ابن إسحاق في قصة مقتل دريد بن الصمة 5 ولم يذكره في قصة هجرة أبي بكر رضي الله عنه إلى الحبشة،أما ابن الدغنة هو سيد قبيلة القارة. أقول: الذي يظهر لي من خلال هذا البحث أن ابن الدغنة المذكور هنا هو سيد قبيلة القارة وهو غير السلمي؛ هذا ما جزم به الحافظ. فتعقبه على الكرماني في محله و الله أعلم. التعقب في تعيين 'إنسان؛' عند شرح الحديث:'"حدثنا إبراهيم بن موسى حدثنا هشام أن ابن جريج أخبرهم قال أخبرني سليمان

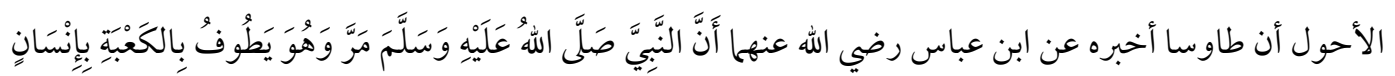

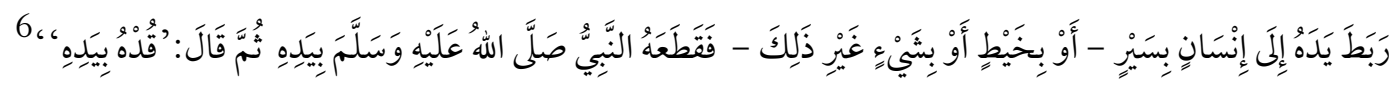
قال العلامة الكرماني: (ب)

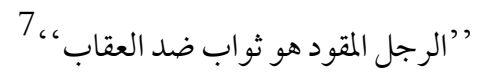

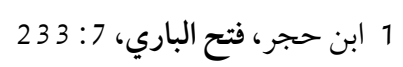

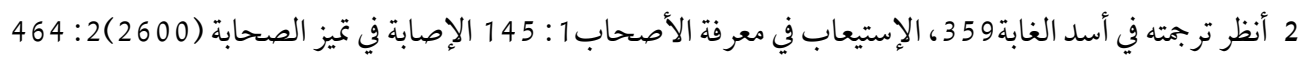

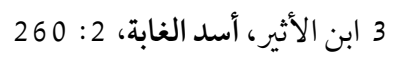
4 ابن عبد البر، الإستيعاب في معرفة الأصحاب ، 1، 1، 145 5 ابن هشام، عبد الملك بن هشام ، السيرة النبوية ،( بيروت، دار الجيل ، 1411ه)، 5 : 122 6 البخاري، الجامع الصحيح ، ح: 1620 7 الكرمانى، الكواكب الدراري،8: 130 


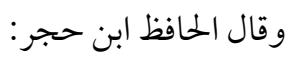

"قوله أو بشيء غير ذلك كأن الر اوي لم يضبط ما كان مربوطا به وقد روى أحمد والفاكهي من طريق عمرو بن شعيب عن أبيه عن جده أن النبي صلى الله عليه و سلم أدرك رجلين وهما مقترنان فقال ما بال

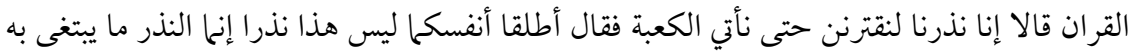
وجه الله وإسناده إلى عمرو حسن ولم أقف على تسمية هذين الرجلين صريحا إلا أن في الطبراني من طريق فاطمة بنت مسلم حدثني خليفة بن بشر عن أبيه أنه أسلم فرد عليه النبي صلى اله عليه و سلم ماله وولده ثم لقيه هو وابنه طلق بن بشر مقترنين بحبل فقال ما هذا فقال حلفت لئن رد الله علي مالي وولدي

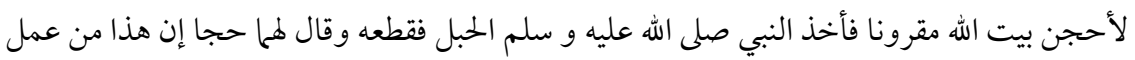
الشيطان فيمكن أن يكون بشر وابنه طلق صاحبي هذه القصة و أغرب الكرماني فقال قيل اسم الرجل

$$
\text { المقود هو ثواب ضد العقاب انتهى ولم أر ذلك لغيره ولا أدري من أين أخذه ، ، } 1
$$

لم يقل أحد من الشراح أن الرجل المقود إسمه ثواب إلا العلامة الكرماني ولم يذكر من أين نقل هذا فلهذا تعقب عليه الحافظ.وأشار معظم الشراح إلى رواية الطبراني أخرجه في المعجم من طريق إبراهيم بن هاشم البعلبكي ثنا محمد بن أبي بكر المقدمي ثنا أبو معشر البراء حدثني النوار بنت عمر : قالت حدثني فاطمة بنت مسلم قالت حدثني خليفة بن بشر عن أبيه بشر أنه أسلم فرد عليه النبي صلى الله عليه و سلم ماله وولده ثم لقيه النبي صلى الله عليه و سلم فرآه هو و ابنه طلقا مقرونين بالحبل فقال: ( ما هذا يا بشر؟) قال: حلفت لئن رد الله علي مالي وولدي لأحجن بيت الله مقرونا فأخذ النبي صلى الله عليه و سلم الحبل فقطعه وقال لهما:'حجّا فإن هذا من الشيطان،2 فإحتمال العلامة الكرماني أن إسم هذا الرجل المبهم هو بشر وابنه طلق هو أقرب إلى الصواب.أقول: بعد دراسة كلا القولين توصلت إلى أن إحتمال الحافظ هو أقرب إلى الصواب لأنه استدل برواية الطبراني أما قول العلامة الكرماني فلا يعرف مأخذه ، فتعقب الحافظ في محله والله أعلم. التعقب في بيان تسمية 'ابن حنظلة'؛ عند شرح الحديث: " حدثنا موسى بن إسماعيل حدثنا وهيب حدثنا عمرو بن يجيى عن عباد بن تميم عن 
در اسة في تعيين الزمان والأماكن و القبائل والأسماء في صحيح البخاري

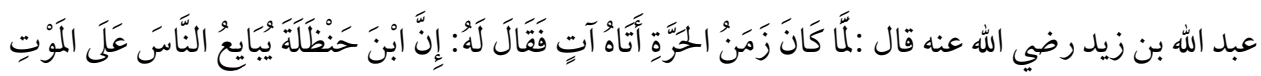

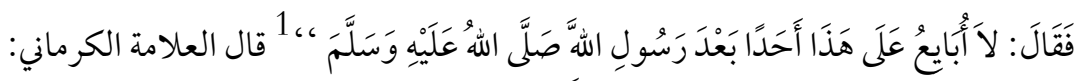

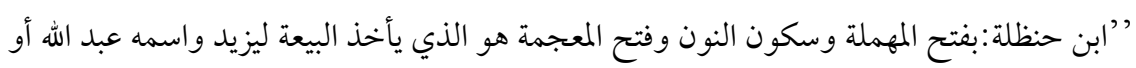

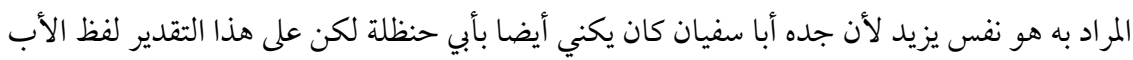

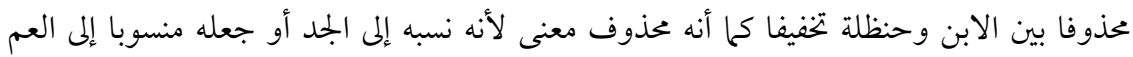

استخفافا واستهجانا واستبشاعا بهذه الكلمة المرة، ، 2

قال الحافظ ابن حجر: - (s)

”قوله لما كان زمن الحرة أي الوقعة التي كانت بالمدينة في زمن يزيد بن معاوية سنة ثلاث وستين كما

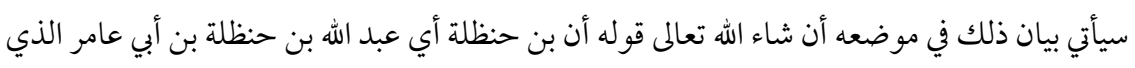

يعرف أبوه بغسيل الملائكة والسبب في تلقيبه بذلك أنه قتل بأحد وهو جنب فغسلته الملائكة وعلقت

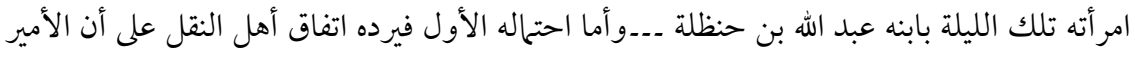

الذي كان من قبل يزيد بن معاوية اسمه مسلم بن عقبة لا عبد الله بن حنظلة وأن بن حنظلة كان الأمير

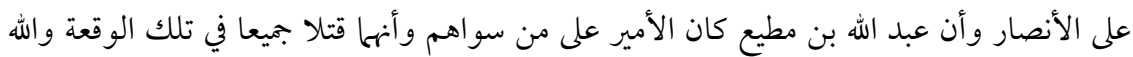

المستعان، ، 3

أخرج الإمام البخاري هذا الحديث في المغازي من طريق إسماعيل عن أخيه عن سليان عن عمرو بن

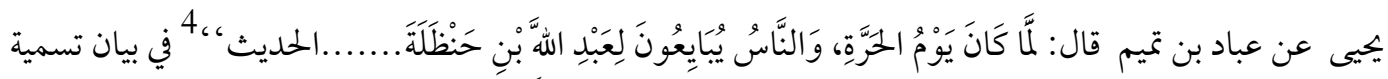

ابن حنظلة جاء العلامة الكرماني بالإحتمال الذي لم يثبت ولذذا تعقب عليه الحافظ وكذا تعقب عليه غيره من العلماء

قال العيني:

”وقال الكرماني ابن حنظلة هو الذي كان يأخذ ليزيد واسمه عبد الله أو المراد به نفس يزيد لأن جده أبا

سفيان كان يكنى أيضا بأبي حنظلة لكن على هذا التقدير يكون لفظ الأب محذوفا بين الأب وحنظلة لئل

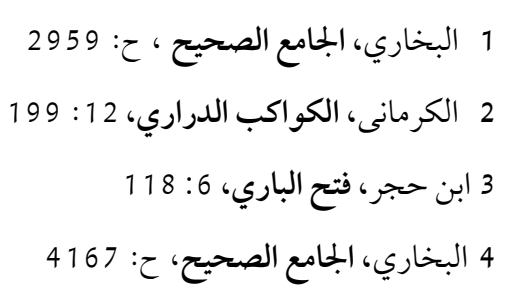




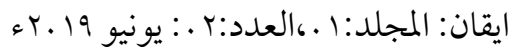

تخفيفا كما أنه محذوف معنى لأنه نسبة إلى الجد أو جعله منسوبا إلى العم استخفافا واستهجانا واستبشاعا

لهذه الكلمة المرة انتهى قلت الكرماني خبط ههنا خبط عشو اء وتعسف في هذا الكلام من غير أصل، ، 1

أقول: بعد دراسة كلا القولين توصلت إلى أن النفصيل الذي ذكره العلامة الكرماني فلا حاجة له؛

و الصو اب ما بينه الحافظ ويؤيده الرواية الذي ذكره الإمام البخاري في المغازي فتعقبه في محله والله أعلم.

التعقب في تعيين نسبة'أم الدرداء؛

عند شرح الحديث:"باب عيادة النساء الرجال وعادت أم الدرداء، رجلا من أهل المسجد من

$$
\text { الأنصار، ، 2قال العلامة الكرماني: }
$$

"قوله :أم الدرداء، بالمد اعلم أن لأبي الدرداء زوجتين كل واحدة منهها كنيتها أم الدرداء والكبرى صحابية والصغرى تابعية والظاهر أن المراد منها ههنا هي الكبرى واسمها خيرة بفتح المعجمة وسكون

$$
\text { وقال الحافظ ابن حجر: ، ولتح }
$$

"قوله وعادت أم الدرداء رجلا من أهل المسجد من الأنصار قال الكرماني لأبي الدرداء زوجتان كل

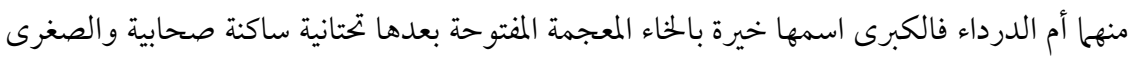
اسمها هجيمة بالجيم و التصغير وهي تابعية ـ...والصغرى عاشت إلى أواخر خلافة عبد الملك بن مروان

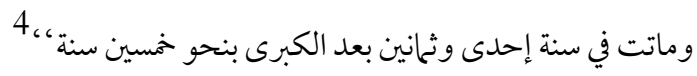

أخرج الإمام البخاري هذا الأثر في الأدب المفرد من طريق زكريا بن يهيى قال حدثنا الحكم بن المبارك قال

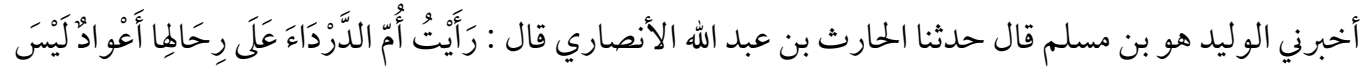

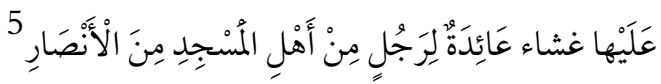

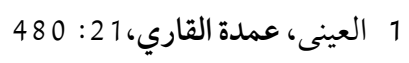
2 3 الكرمانى، الكواكب الدراري، 20: 184 4 ابن حجر، فتح الباري، 10 : 117 5 بخاري ، محمد بن اسهاعيل، الأدب المفرد ( الرياض:مكتبة المعارف للنشر والتوزيع، 14 14ه)، ح: 530 
در اسة في تعيين الزمان والأماكن والقبائل والأسماء في صحيح البخاري

الحارث بن عبد الله: قال الإمام البخاري: الحارث بن عبيد الله الانصاري، يعد في الشاميين، قال لنا زكريا

حدثنا حكم بن المبارك سمع الوليد بن مسلم قال حدثنا الحارث بن عبيد الله قال: رأيت ام الدرداء تعود رجلا من

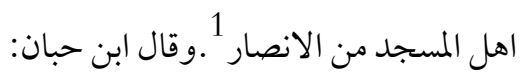

"الحارث بن عبيد الله الأنصاري من أهل الشام يروى عن أم الدرداء روى عنه الوليد بن مسلم، ، 2 قد ثبت بتخريج الأثر المذكور أن أم الدرداء هنا ليست الكبرى كما زعم العلامة الكرماني،لأن أم الدرداء الكبرى ماتت قبل موت أبي الدرداء في خلافة عثمان والتابعي الحارث بن عبيد الله الأنصاري لم يلحق بها، وهو يروي عن أم الدرداء الصغرى وهي عاشت إلى أواخر خلافة عبد الملك بن مروان.فأقول: بعد دراسة كلا القولين توصلت إلى أن أم الدرداء المذكورة في الأثر هي الزوجة أبي الدرداء الصغرى وليست الكبرى والصواب ما جزم به الحافظ وتعقبه على العلامة الكرماني في محله و الله أعلم.

التعقب في تعيين الاسم 'معاوية':

عند شرح الحديث: 'تلك الحديقة في موضع قصر بني حديلة الذي بناه معاوية، ،3 قال العلامة الكرماني:

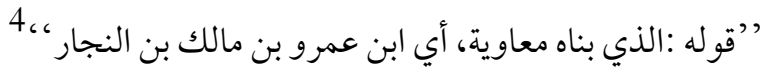
قال الحافظ ابن حجر:

"وأما قصر بني حديلة وهو بالمهملة مصغر ووهم من قاله بالجيم فنسب إليهم القصر بسبب المجاورة وإلا فالذي بناه هو معاوية بن أبي سفيان وبنو حديلة بالمهملة مصغر بطن من الأنصار وهم بنو معاوية بن عمرو بن مالك بن النجار وكانوا بتلك البقعة فعرفت بهم فلما اشترى معاوية حصة حسان بني فيها

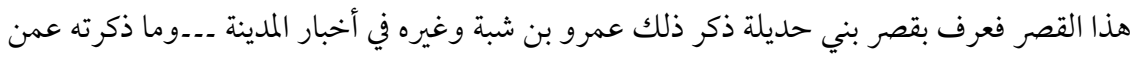
صنف في أخبار المدينة يرد عليه وهم أعلم بذلك من غيرهم، ، 5

1 بخاري ، محمد بن اسماعيل ، التاريخ الكبير،( حيدر آباد ، الدكن ،دائرة المعارف العثمانية) 2:275 2 2:275 2:2 3 4 5 ابن حجر، فتح الباري، 5 : 


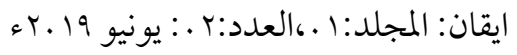

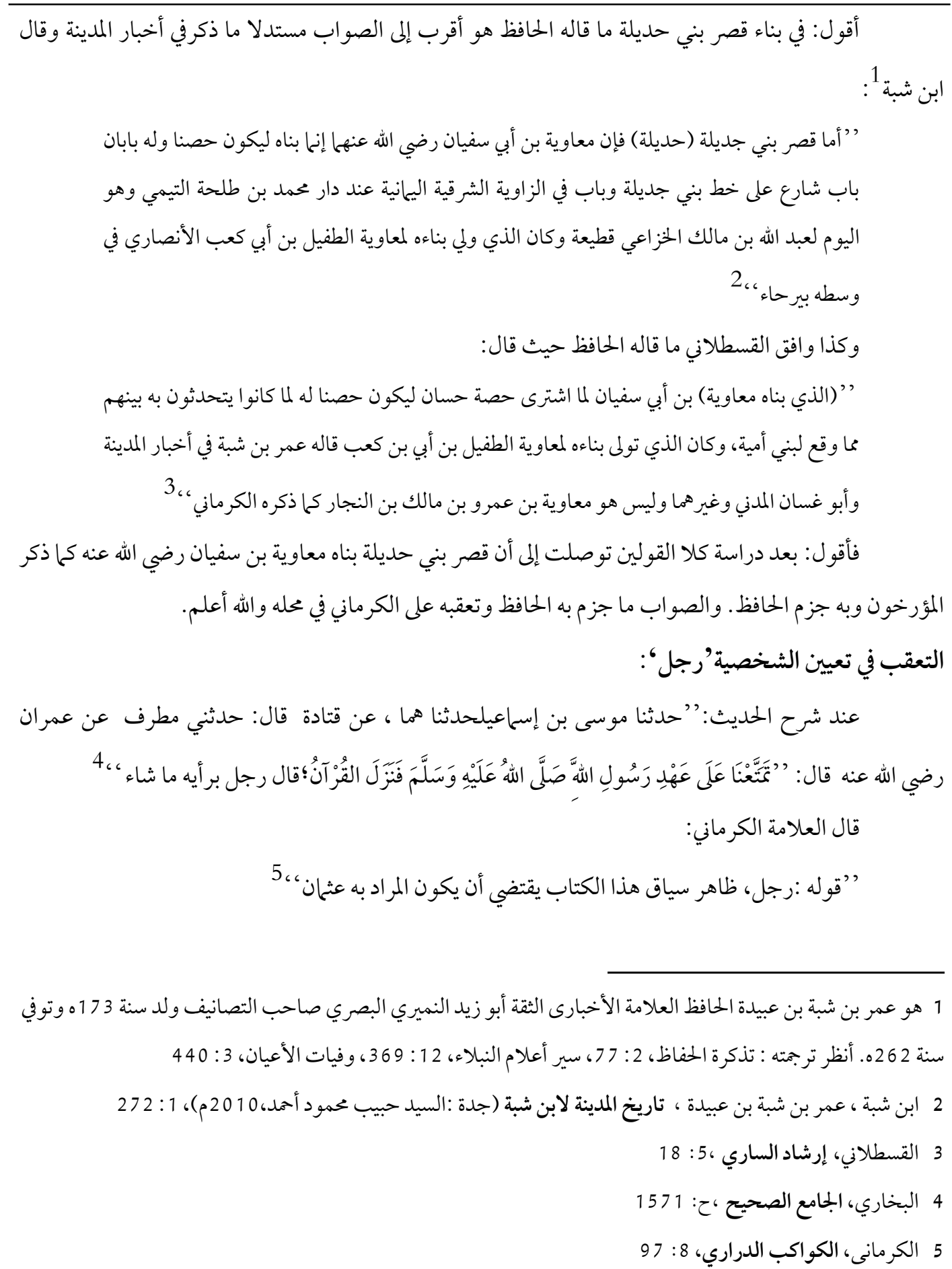


دراسة في تعيين الزمان والأماكن والقبائل والأسماء في صحيح البخاري

وقال الحافظ ابن حجر: - ماف:

”قوله قال رجل برأيه ما شاء وفي رواية أبي العلاء ارتأى كل امرئ بعد ما شاء أن يرتئي قائل ذلك هو

عمر ان بن حصين ووهم من زعم أنه مطرف الر اوي عنه لثبوت ذلك في رواية أبي رجاء عن عمران كما ذكرته قبل --.. وكأن من بعده كان تابعا له في ذلك ففي مسلم أيضا أن بن الزبير كان ينهى عنها وبن

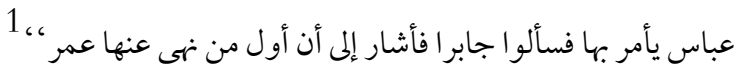
ما قاله الحافظ في تعيين الرجل هو أقرب إلى الصواب ووافقه أكثر الشراح مثلاً قال النووي: ”قال رجل بر أيه ما شاء يعنى عمر بن الخطاب رضي الله عنه، ، 2 قال ابن دقيق العيد: - n

”قوله :'قال رجل برأيه ما شاء “هو كما ذكر في الأصل عن البخاري: أن المراد بالرجل عمر عنه، 3 وكذا إختار هذا المر اد بدر العيني بعد ذكر عدة أقوال فيه حيث قال: ” قوله قال رجل قال الكرماني ظاهر سياق هذا الكلام يقضي أن يكون المراد به عثمان رضي الله تعالى عنه وقال ابن الجوزي كأنه يريد عثمان وقال ابن التين يجتمل أن يكون أبا بكر أو عمر أو عثثان وفيه تأمل لا يخفى وقال النووي والقرطبي يعني عمر بن الخطاب وحكى الحميدي أنه وقع في البخاري في رواية أبي رجاء عن عمران قال البخاري يقال إنه عمر أي الرجل الذي عناه عمر ان بن حصين قيل الأولى أن يفسر بها عمر فإنه أول من نهى عنها وأما من نهي بعده في ذلك فهو تابع له، بـال وكذا قال القسطلاني: ”قال: رجل برأيه ما شاء، هو عمر بن الخطاب لا عثمان بن عفان لأن عمر أول من نهى عنها فكان من بعده تابعًا له في ذلك، ففي مسلم أن ابن الزبير كان ينهى عنها وابن عباس يأمر بها فسألو ا جابرا فأشار إلى أن أول من نهى عنها عمر، ، 1 2 النووي ، يحيى بن شرف ، المنهاج شرح صحيح مسلم بن الحجاج ( بيروت: دار إحياء التراث العربي ، 1392ه)،8: 205 3 ابن دقيق العيد، محمد بن علي، إحكام الأحكام شرح عمدة الأحكام (القاهرة:مؤسسة الرسالة ، 1426 ه )، 1:322 4 5 القسطلاني، إرشاد الساري ،3: 136 


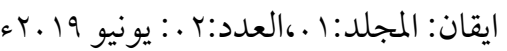

$$
\begin{aligned}
& \text { فأقول: بعد الدراسة توصلت إلى أن المراد برجل في قوله (قال رجل برأيه ما شاء) هو عمر بن الخطاب } \\
& \text { رضي الله عنه لأنه أول من نهى عن التمتع، وجزم به الحافظ ورأيه أقرب إلى الصواب و الله أعلم. } \\
& \text { نتائج البحث: } \\
& \text { توصلت من خلال دراستي لهذا الموضوع الهام إلى نتائج ذات أثر كبير فأشير هنا إلى أهمها وهي ما يلي: } \\
& \text { 1- عني العلماء عناية فائقة من منطلق حرصهم الشديد أن تبقى السنة مطهرةً نقية من شوائب الوضع } \\
& \text { والتزوير،فتناولو الأحاديثَ بالفحص والتنقيب والسبر،وأبلوا في ذلك بلاءً حسنًا،فكان بذلك أن اهتموا } \\
& \text { بصحيح البخاري، فوضعوا له الشروح، وكتبوا عليه الحواشي، وعلقوا على متونه وأسانيده، وناقشوا } \\
& \text { مشكاته و ألفاظه و كلم|ته، ووضعو اله التكملات، وترجموا لرجاله ورو اته. } \\
& \text { 2- اهتم العلماء المحدثين في بيان مَا ورد في متون الأحاديث ما أشكل على عامة الناس في تعيين الزمان والأماكن } \\
& \text { و القبائل والأسماء. و الفت كتب مستقلة في هذه الفنون، وقداستفاد الشارحون من هذه الكتب. } \\
& \text { 3- أن الإمام الكرماني عني عناية فائقة لصحيح البخاري عند شرح أسانيده، و متونه، بجانب متميّز فيه، استفاد } \\
& \text { منه الشارحون بعده . } \\
& \text { عليه إضافات جليلة لا يُمكن إنكارها. } \\
& \text { 5- وقد توصلت إلى أن الحافظ ابن حجر عنده خبرة أكثر من الإمام الكرماني في تعيين الزمان والأماكن و القبائل } \\
& \text { والأسماء في متون الأحاديث عند شرح صحيح البخاري. }
\end{aligned}
$$

